\title{
FEMINIST PEACE AND SECURITY IN THE MIDDLE EAST AND NORTH AFRICA
}

Dr Zeynep Kaya, London School of Economics

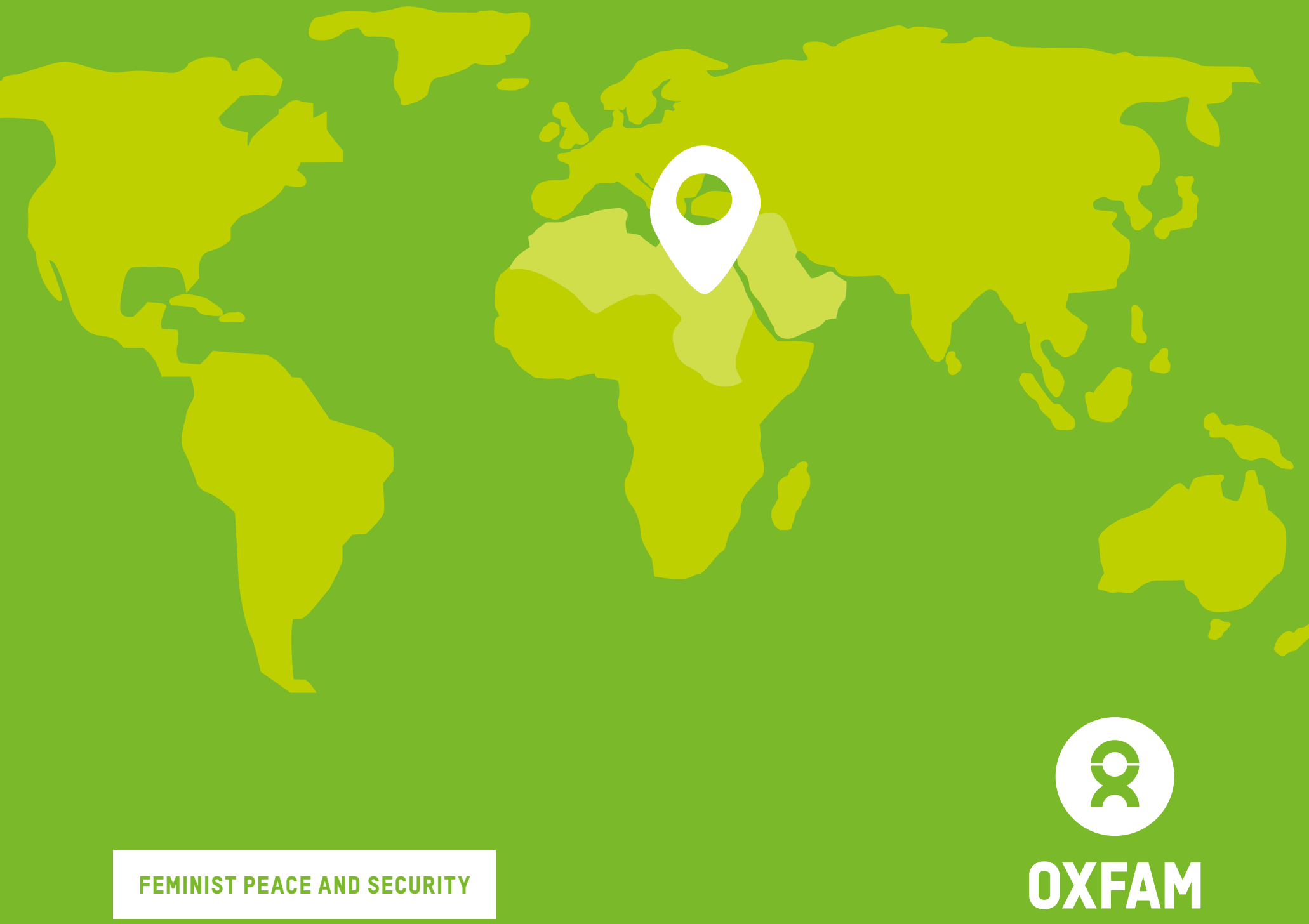


(c) Oxfam International September 2020.

This paper was written by Dr Zeynep Kaya. Oxfam acknowledges the assistance of Mathew Truscott, Helen Wishart, Nesrine Aly, Michelle d' Cruz, and Jacqueline Awiti in its production. It is part of a series of papers written to inform public debate on development and humanitarian policy issues.

For further information on the issues raised in this paper please email advocacy[oxfaminternational.org

This publication is copyright but the text may be used free of charge for the purposes of advocacy, campaigning, education, and research, provided that the source is acknowledged in full. The copyright holder requests that all such use be registered with them for impact assessment purposes. For copying in any other circumstances, or for re-use in other publications, or for translation or adaptation, permission must be secured and a fee may be charged. E-mail policyandpractice@oxfam.org.uk.

The information in this publication is correct at the time of going to press.

Published by Oxfam GB for Oxfam International under ISBN 978-1-78748-647-8 in September 2020. D0I: 10.21201/2020.6478

Oxfam GB, Oxfam House, John Smith Drive, Cowley, Oxford, OX4 2JY, UK. 


\section{INTRODUCTION}

Conflict has escalated in the Middle East and North Africa (MENA) on a dizzying scale since the 2011 Arab uprisings. The region has witnessed conflicts between states, between states and non-state actors, and conflicts in which international actors play a major role. These conflicts are best seen as a form of the 'new wars' that emerged globally after the end of the Cold War, in which non-state actors are increasingly influential and civilians are affected by conflict ever more directly and in multi-faceted ways. Most notably, terrorism has become the most significant cause of violence as a new generation of violent non-state actors has emerged. Conflicts that originated in particular parts of the region have spread to other parts, drawing in regional and international actors along the way. The power and security vacuums that emerged due to the chaos of war and weak state institutions, especially in the fields of security and the rule of law, have been filled with increasing numbers of local, national, regional and international actors. Nowhere is this more evident than in the transformation of the Syrian war into something more akin to an international proxy war; although the current conflicts in Libya, Yemen and Iraq also display these hallmarks. The net effect is a heightening of local tension and conflict between actors and a rendering of the resolution of the conflict even more complicated.

Terrorism has

become the most significant cause of violence as a new generation of violent non-state actors has emerged.

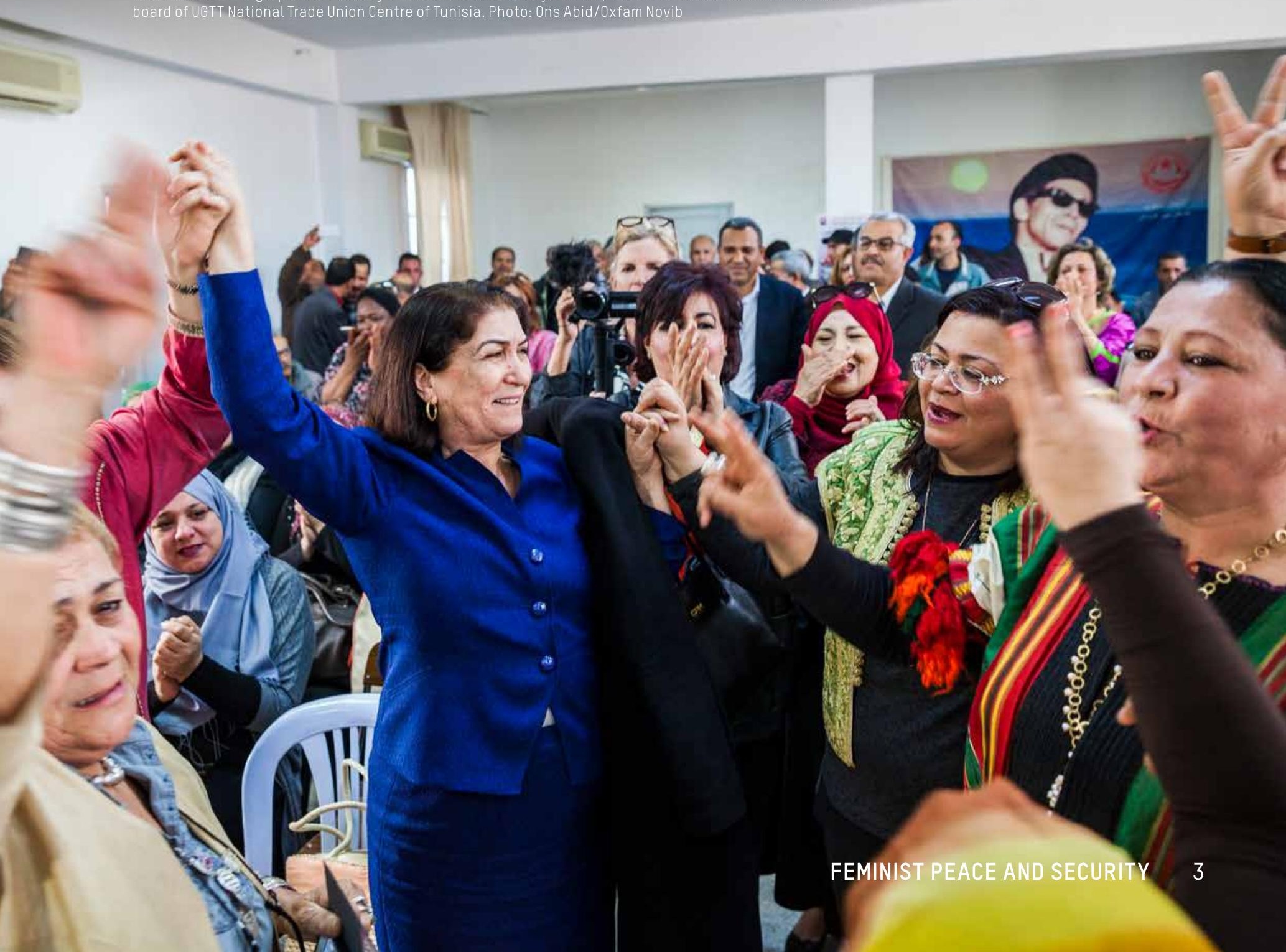


It is within this context that several issues have become more prevalent which challenge women and women's rights activism: including the role of widespread patriarchal values which institutionalize militarized masculinity; the proliferation of arms; a lack of accountability; and an enabling environment for exploitation and violence. Conflict-related displacement, both internally and externally, has become pervasive across the region and this has genderspecific impacts. Occupation in Palestine, the protracted humanitarian crisis in Yemen, heightened militarization in Iraq, the absence of the rule of law in Libya and the highly complex Syrian war, among others, are all conditions that directly or indirectly induce sexual, gender-based and other forms of violence that impact women disproportionately and prevent their effective and meaningful participation in preventing and resolving conflict. ${ }^{+}$

As such, women's organizations in the MENA region face not only the challenge of conflict, but also the gender-based discrimination and violence that inevitably is exacerbated in the context of this conflict. This is further compounded by the fact that dominant international discourses of peace and security have become increasingly militarized, and prioritize ending conflicts rather than preventing them, hindering genuinely transformative feminist peace and security. This is even the case with the Women, Peace and Security (WPS) agenda, which many initially hoped would be transformative and empowering. Instead human rights, and women's rights in particular, have become issues of lower priority when it comes to discourses of peace and security. So far, three states in the region have developed National Action Plans to implement the WPS agenda: Iraq, Palestine and Jordan. But international humanitarian and development work is typically carried out within particular (securitizing) frameworks, and most of the time implemented with a one-sizefits-all approach.

There has been an increase in the number of external international donors, which has changed the landscape of local feminist and women's rights activism. In recent years such donor activity has come to be seen by many as instrumentalizing women's empowerment and reducing it to something that is pursued mainly in the name of conflict reduction rather than for its own sake. It can also be seen as reinforcing securitizing trends through the rise of ideas like countering and preventing violent extremism ICVE, discussed in more detail below). In some cases, local activist groups have jumped on board with this donor-led agenda and have reframed their agenda in line with donor expectations; often doing so in order to win funding and ensure their survival. Thus, while the political and security contexts differ in each country, there is nevertheless a clear similarity in how global policies and international responses are manifesting locally, as well as how they are disproportionately affecting women in general, and women-led local civil society and human rights defenders in particular. There are specific overlaps, clashes and tensions between international frameworks and local women's activism.

Adopting a feminist lens allows us to critique power, structures and institutions, and to posit a more holistic vision of peace and security that is truly people-centred. A feminist analysis can offer multiple advantages over the current securitized approach, including: a potentially genuinely transformative vision of peace and security; a gendered understanding of the root causes of conflict and the continuum of violence through peace and conflict; and a nuanced and context-sensitive approach that safeguards against future conflicts with women peacebuilders at its heart.

\author{
Adopting a feminist \\ lens allows us to \\ critique power, \\ structures and \\ institutions, and to \\ posit a more holistic \\ vision of peace and \\ security that is truly \\ people-centred.
}




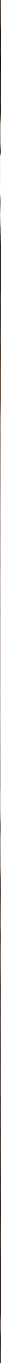

This paper explores feminist transformative discourses and visions of peace and security and analyzes their intersection with dominant international frameworks on women's rights in fragile and conflict contexts in the MENA region. The paper begins by providing an overview of the nature of existing international frameworks on gender, peace and security, with a focus on the WPS agenda and how and why it overlaps and differs from the more comprehensive feminist conceptions of peace and security internationally and locally. In her most recent book, Cynthia Enloe made the point that the patriarchal form of masculinity and patriarchy is persistent, and despite the progress made in challenging patriarchal structures and gender discrimination, patriarchy finds ways of creeping back. She suggests strategies, skills and feminist self-reflection to find ways in which we sustain patriarchy. ${ }^{2}$

The rest of the paper applies a critical perspective to the WPS agenda and focuses on issues in which 'gender-sensitive' international frameworks are leading to inadvertently contradicting outcomes for achieving feminist peace and security: responses to sexual violence in conflict; instrumentalization of WPS through CVE; the politics of donor funding and the resilience policy that is being increasingly adopted in humanitarian and development work. ${ }^{3}$ These issues perpetuate the traditional military, colonial and patriarchal mentality that perceives women as victims; they overlook the underlying inequalities and imbalances of power at national and global levels and they put the responsibility to solve problems/overcome difficulties on the 'underdeveloped'. This is despite the fact that women are often the first responders in a crisis, or are involved in grassroots mediation. Women who could promote women's interests and have a history of campaigning for women's rights
Women who could promote women's interests and have a history of campaigning for women's rights and participation are often overlooked in formal national and international peacebuilding processes. 
and participation are often overlooked in formal national and international peacebuilding processes. There is a lack of robust analysis and examination of both small- and larger-scale efforts and initiatives by women to promote peacebuilding in fragile and post-conflict contexts.

\section{CRITICALLY APPRAISING THE WPS AGENDA}

The Women Peace and Security agenda while appearing to have emerged from decades of women's rights activism, has the potential to be truly transformative; but by being the product of a number of UN Security Council resolutions it has become part of the very system itself. There has been an increase in more inclusive global and transnational platforms when it comes to security and conflict; but the systems and international peace and security institutions which are in place are more rigid and harder to transform. UN Security Council decisions with regards to conflict, security and war are still typically dominated by the interests of powerful states and dominant normative discourses and mentalities. Conceptions and practices of international security are historically constructed based on the behaviour of men in positions of power. State interest and security is associated with traditional concepts of power, whether defined in material or normative terms. There has been a post-war consensus on an increased emphasis on the role of soft power, ideas for shaping international relations and institutions, and an emphasis on global and multilateral negotiations for resolving issues. However, security and war are still defined in terms of masculinities that emphasise militarism and power. It could be argued that increasingly there appears to be a return by some of the nations with the biggest armies to using 'hard power' as a means of resolving disputes, and this has resonated through the UN Security Council by the repeated use of vetoes by some states to UNSC resolutions. This is an aggressive form of masculinity that perceives survival in the conflictual international system as possible through war-capable states and heroic masculine warriors as protectors and defenders and this has resonated through the UN Security Council by the repeated use of vetoes by some states to UNSC resolutions. This is an aggressive form of masculinity that perceives survival in the conflictual international system as possible through war-capable states and heroic masculine warriors as protectors and defenders. ${ }^{4}$

Women, Peace and Security is as much a part of global normative discourses and power structures as it is the product of transnational women's rights activism in the 1990s and preceding decades. The WPS agenda is composed of seven UN Security Council Resolutions; it is part of the international normative agenda on women and it incorporates some core feminist principles into its framing. WPS's first resolution 1325 is a pioneering commitment that recognizes the importance of women and gender issues to peace and security. This relies on the ideas that gender equality is a value in itself and that women are naturally predisposed to peace, and thus a stronger force for resolving conflicts. The WPS agenda makes gender equality, women's empowerment and representation central to processes of conflict, conflict-prevention, post-conflict reconstruction and peacebuilding processes. Its resolutions on women's empowerment emphasise the need for women's increased participation in formal conflict resolution and peace processes. They also recognize the importance of the conflict resolution and peacemaking work done by local

\author{
Women who could \\ promote women's \\ interests and \\ have a history of \\ campaigning for \\ women's rights and \\ participation are \\ often overlooked \\ in formal national \\ and international \\ peacebuilding \\ processes.
}


women's organizations and advise consulting them. SCR 2122 specifically urges consultations with socially or economically excluded groups of women. WPS resolutions also encourage increasing the number of women in police and military peacekeeping missions. They bring new openings for women's participation, increase pressure to reduce conflict-related sexual violence and highlight the importance of the peacebuilding work done by local women. ${ }^{5}$

But the WPS agenda also embodies some key tensions which undermine its potential. It is an agenda with one foot planted in traditional security conceptions and structures and the other in transnational and feminist peace activism. It is caught between an urge to reflect existing international power structures and normative frameworks and the desire to eliminate, or at least reduce, gender inequalities and include women in peacebuilding.

Although the WPS agenda is widely welcomed by feminist scholars and activists, it does not represent feminist peace and feminist security, mainly because of its dual position of being both an agenda for feminist women and for the UN Security Council. The UNSC's tendency to associate peace with security has led WPS to also be framed within security discussions. This led the WPS agenda to move away from an anti-war and rights-based agenda to one for making wars safer for women and using military measures to protect women from sexual violence. Its provisions have come at some cost to key feminist goals such as strengthening women's meaningful participation, conflict prevention and disarmament. Its goals on women's participation have also remained mostly unimplemented. Even its empowerment dimension is primarily protective rather than giving women agency. ${ }^{6}$

The WPS agenda has also been selective and ritualistic in its engagement with the feminist perspective. The agenda is limiting, in that it reduces the spaces and opportunities for influential and transformative actions. WPS's conceptual underpinnings rely on a liberal feminist paradigm rather than a wider spectrum of feminist approaches and conceptions of peace. It excludes the anti-war approaches and feminist critiques of military solutions. ${ }^{7}$ There is no homogenous or commonly accepted form of feminist peace and security, and feminism can take different forms or focus on different issues across the world. Moreover, there are divisions over certain issues, such as on whether feminism should advocate for women's inclusion in security forces. However, most feminists adopt more comprehensive definitions of peace and security that see violence as a continuum and consider economic and social justice crucial for peace and security. ${ }^{8}$ They put emphasis on human security rather than militarized and traditional security.

The net effect is that WPS's selective approach and its underpinnings in militarized security negatively affect local civil society organizations by making them re-frame their existing work on women's rights to fit with the international security agenda. Western donors adopted the feminist perspective, albeit a liberal one, through WPS and have used their money to promote and implement it. In this work, the security concerns of the UN Security Council and the donor states have led to specific forms of WPS being implemented and pursued locally and these forms generally reflect the framing of the UN and dominant states. They ensured that money is available for certain kinds of work prioritized in their agenda. Implementers and civil society organizations chose to and/or were forced to carry out that kind of work in order to gain vital international support and funding. There can be little doubt that this has led to an increased focus on
The agenda is limiting, in that it reduces the spaces and opportunities for influential and transformative actions. 
more women in the security sector, greater women's political participation and women's protection from sexual violence. But these developments have come at the cost of limited understandings and interpretations of peace and security in general and WPS in particular. This is a limited understanding because it overlooks the feminist agenda that incorporates actual inclusion, meaningful participation, conflict prevention through disarmament and transformative change, as explained below.

\section{Inclusion}

Despite its emphasis on the participation of women in conflict resolution and peacemaking processes, the WPS agenda can be exclusionary and weak in intersectional analysis. It mainly focuses on adding women into existing structures and processes; however, it fails to take women's responses to and conceptions of conflict and peacebuilding seriously. For instance, in the case of Palestine, some women's agency can be informed by a logic of violent or non-violent resistance against unequal power structures and the occupation, not by a liberal peace model based on dialogue. The National Action Plan (NAP) to implement WPS in Palestine was developed by women who were urban, professional and largely secular, and excluded women active in Islamist political parties and internally displaced women. In Iraq, the preparation of the WPS national action plan was not an inclusive process either. It was led by a limited number of women's rights organizations and did not carry out consultations with women from different walks of life or incorporate their different needs and expectations. For instance, displaced women were entirely excluded, not only during its preparation but they were also not discussed in the NAP itself. Local women engaged in conflict resolution were not included; they wrote letters to international actors requesting their inclusion, but they were duly overlooked.

\author{
Despite its \\ emphasis on the \\ participation of \\ women in conflict \\ resolution and \\ peacemaking \\ processes, the \\ WPS agenda can \\ be exclusionary \\ and weak in \\ intersectional \\ analysis.
}

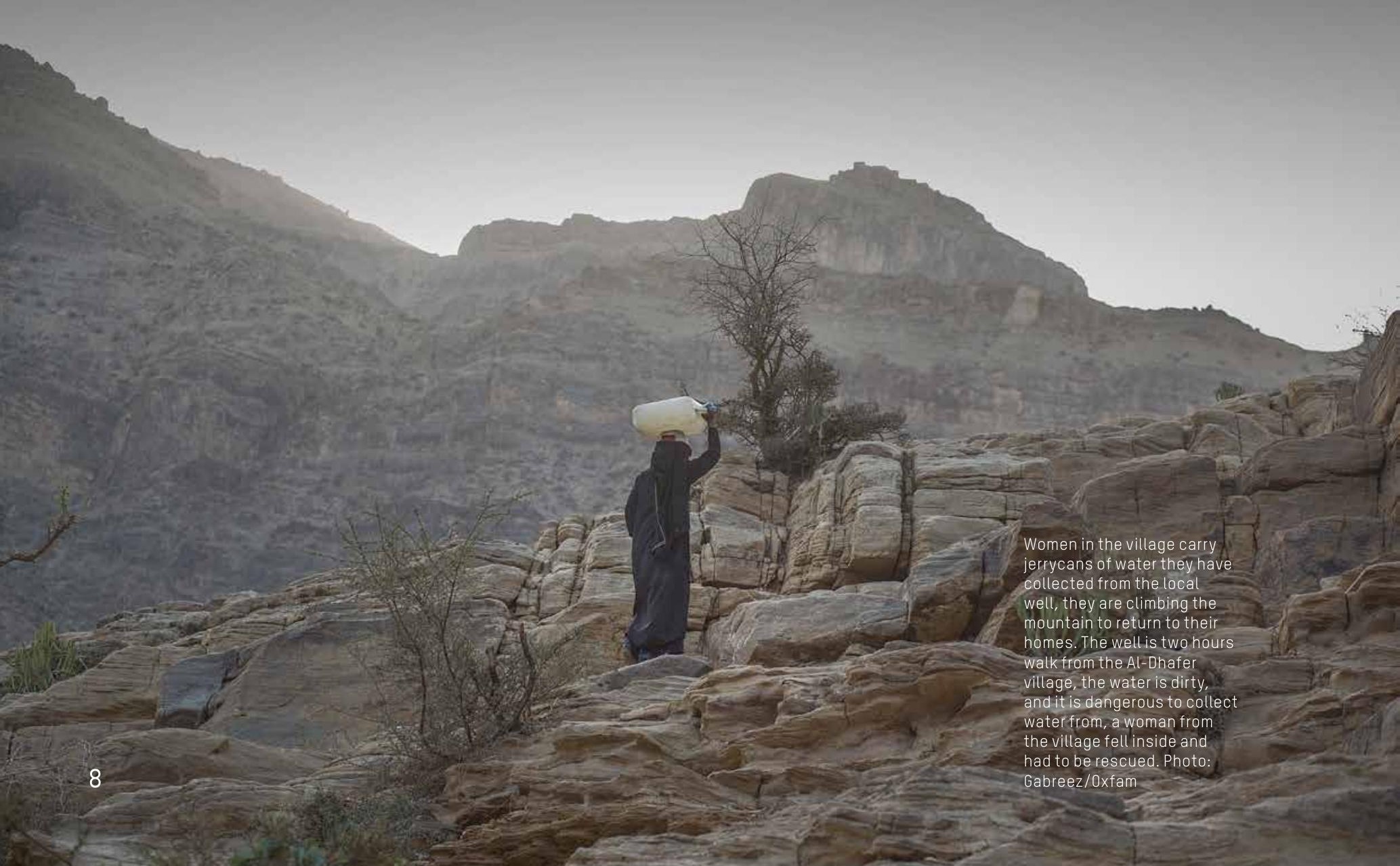


Such practices lead to some women's experiences and voices being silenced and they exacerbate fragmentation and rivalries between woman activists on the ground. The WPS agenda views women in their totality as a unitary group. It has a particular framing of gender, peace and security that leads to disconnection between pre-approved solutions and complex local realities. ${ }^{9}$ The existing WPS paradigm categorizes women as a singular group, viewed as peacemakers as a whole, with similar needs, interests and agencies simply because of their gender. This overlooks other intersecting factors that shape women's needs and expectations, such as class, religion, ethnic or racial background, political orientation or geographical place of residence.

This shows the necessity of adopting an intersectional approach to inclusion, to ensure that women with different backgrounds and perspectives are included in a full awareness of the disadvantages caused by unequal international structures. A one-size-fits-all approach may create divisions and exclude certain groups and perspectives that do not fit in the WPS framing. Instead, WPS should facilitate local women's peace and human rights organizations to generate their own conflict resolution and peacemaking initiatives, and support these. This is essential for being able to truly transform the international peace and security agenda, rather than merely adding women into existing structures and processes. ${ }^{10}$

A similar picture is evident when it comes to women's engagement in peacemaking processes. The emphasis of WPS on including women in peacemaking processes tends to be reductionist, and frames women's inclusion in an instrumental light. Leaving aside the quality of their participation, even in terms of the volume of women's engagement, the WPS agenda has not been particularly successful. The number of women in peace negotiations has not increased significantly since the first WPS resolution was adopted. The SCR 2242 in 2015 made a push for women's meaningful participation, but this may not make a difference because the underlying factors in the WPS approach that hinder such participation are still there, such as the top-down and UNSC-led nature of the WPS agenda. Each implementing state or international agency interprets the principles of WPS in a way that suits their interests, often making token references to women's participation and seeking to include women in existing processes, rather than rethinking. That is not to say that the effort to include women in such processes is not a positive development, but this should not be done in a selective way. The WPS agenda should be able to adapt to local needs and demands, and different women's agendas should be allowed to change the existing peacemaking processes. Locally driven processes may be a way to help deliver more inclusion, as the local level can be more open to influences from the non-military and non-elite, and can be more inclusive towards women's organizations. ${ }^{11}$

The main discourse on the roles of women in peacebuilding among the donor community focuses on women's descriptive participation (presence in politics) rather than substantive participation (promotion of women's perspectives and interests). In Syria and Yemen, women are included in formal peace processes, but they are expected to speak with one voice and to only represent their gender. The efforts to include women in peace processes in Libya have been disappointing because the UN and state have not ensured the meaningful participation of women. In Iraq, formal peacebuilding often relies on tribal hierarchy, religious leaders and the established political actors - restricted spaces for women's involvement. To be involved, women often have to rely on partisan support and thus become an extension of their sponsor. In 2006 the
The WPS agenda should be able to adapt to local needs and demands, and different women's agendas should be allowed to change the existing peacemaking processes. 
Iraqi government adopted a national reconciliation programme and formed a National Reconciliation Commission to promote the values of tolerance, non-violence and rule of law. Women were not included in the formation of the programme and were instead given the Office for Women in the National Commission, which was weak and had no real programme or intent to activate the role of women in reconciliation. In July 2017 UNAMI in collaboration with UN Women and Gol National Reconciliation Committee, Office of the PM's Women and Gender Affairs Department, organized a meeting with leading Iraqi women to discuss women's participation in Iraq's National Reconciliation process. But no real progress has been made.

In Israel, and Palestine, with the Intifadas, a reaction to the occupation emerged and advanced alongside a challenge to the prevalent norms in Israel that excluded women from public affairs, especially when it came to security and conflict. This led to the development of the women's peace movement in Israel and cooperation between Israeli and Palestinian women. For instance, the Women in Black movement facilitated women with different political views to participate in peace activism. The feminist peace movement in the 1990s evolved into one that does not impose one single perspective, and instead highlights the differences between participants and strives to ensure equal participation for different groups (Palestinian, Ashkenazi and Mizrachi women). In this way, it represented a co-existence of different concepts and experiences of feminism together and sought to facilitate dialogue between them. It also gave each group agency, and empowered them by giving them a voice. Clearly the division of these groups along identity lines is somewhat problematic, mainly because it essentializes and tribalizes identity constructions and creates monolithic groups, ${ }^{12}$ but crucially the movement does not push for a uniform voice and in so doing empowers women's agency. However, this changed after the second Intifada. The collapse of the peace talks and deepening of divisions between Israelis and Palestinians also deepened divisions among women activists. Many Palestinian women's organizations began to focus on their unique challenges that emerge from occupation, distancing themselves from their Israeli counterparts.

The state of feminist peace activism in Israel today shows that a feminist peace critique of the Israeli policy of occupation is situated on a fragile political platform imbued with sensitivities, resentments and occupier/occupied tensions, which render local activism challenging. Inclusion must not ignore the root causes of the conflict, or the impact on the peacebuilding processes. The challenge facing WPS when it comes to inclusion is that embracing a role as 'peacemakers' renders it hard for women to express critical and anti-militarist views under the WPS agenda. ${ }^{13}$ Indeed, Jewish women's organizations, such as Machsom Watch, have an established history of monitoring and highlighting violations of women's human rights by the Israeli security forces and resisting these practices. ${ }^{14}$ What is more, both Israeli and Palestinian women have engaged in Peace Marches since 2014, not only to promote a peaceful agreement between Palestine and Israel but also for a right to gender-equal participation in developing a resolution. The marches are organized by Women Wage Peace, which defines itself as a non-ideological and non-affiliated organization that brings a diverse group of people for a shared goal of peace. Yet, several Palestinian and civil society organizations criticized the march in 2017, claiming that it actually promoted a normalization of the occupation without acknowledging the severe injustices it causes, and many Palestinian women activists feared they were being used by Israeli women in this process.
The marches are organized by Women Wage Peace, which defines itself as a non-ideological and non-affiliated organization that brings a diverse group of people for a shared goal of peace. 

and security. These references appear to confirm the view of women as a vulnerable group needing, in particular, protection from sexual violence. WPS has reinforced the idea that securing international peace relies on military strength and securitized states. Instead of pursuing feminist goals for permanent peace, the WPS limited itself to women's participation in existing conflict-resolution processes, disarmament in post-conflict communities and protection of women during conflict. ${ }^{16}$ Moreover, SCR 2242 not only reifies the securitized responses but also calls for the use of WPS in CVE, a highly securitized policy. Instead of focusing on the root causes of conflict and preventing conflict, the WPS agenda has focused on including women in ongoing processes. Although this is desirable based on the principle of gender equality, it has weakened feminist opposition to war, strengthened the view that women need protection, and made WPS an instrument of military and securitized ways of thinking. ${ }^{17}$

Seeing gender inequality as a cause of war and conflict and a threat to international security may feed into the western discourses that represent 'southern' or 'non-western' women in the 'global south' as universally victimized and in need of external support. Discourses about the need to 'save' these women risk provoking a local backlash against women's activism in conflict and post-conflict contexts. In such contexts, such as in Iraq, women become associated with 'foreign' interventions and 'foreign' military agendas and are therefore violently targeted by local actors. ${ }^{18}$ This threat was prominent during the sectarian violence but has not abated. In 2018 a series of high profile killings took place including a well-known women's rights activist, Soad Al-Ali, and a beauty queen visible in social media, Tara Fares. A key underlying reason for these attacks is that Islamist militia groups and conservative sections of the society perceive women who advocate women's rights as importers of western values that 'contradict' social and religious norms in Iraq. Such a view entirely overlooks long-term Iraqi women's rights activism. What is important is that the anti-western ideologies and movements use this rhetoric and violence as a mode of control and suppress freedom of expression and civic activism in Iraq. ${ }^{19}$

\section{Transformative change}

Clearly, it is important to understand the specific ways in which violence against women continues in peace and conflict. Understanding continuities in violence beyond a 'peace process' and into 'peace time' helps tackle the root causes of both gender inequalities and conflict. It is essential to understand the existing causes of violence in the specific context of each country, as conflict amplifies existing trends. Indeed, for many feminist scholars it is only through this process that genuine transformation is possible and that 'positive peace' for women beyond just the elimination of violence can be achieved. Peace is not just an absence of armed conflict, but it is also being able to exercise one's social, economic and political freedoms without fear of violence, backlash and discrimination. Therefore, many feminist approaches argue that a narrow understanding of peace and security should be challenged to ensure the promotion of social justice, elimination of violence and to generate transformative change. ${ }^{20}$

Indeed, the feminist perspective offers a different conception of peace and security that undermines traditional assumptions and that can create a more just, lasting and equal peace. Now that WPS is part of the international normative agenda on women, potentially this can be used to change the 
security mentality that sees peace as an absence of violence. However, at the moment this potential is not being realised, in part because the WPS agenda tends to divide feminists who focus on women's participation based on the equality principle, and feminists who believe in the same principles but also seeks to carry out anti-militarist work. ${ }^{21}$ While WPS increases women's participation based on equality, this does not guarantee positive peace. In fact, as it is currently conceived, it is more likely to lead negative peace rather than genuine transformation.

There is a need, therefore, to reintegrate feminist conceptions of positive peace into the WPS agenda and to push it beyond its short-term security focus. According to feminist peace and security, conflict prevention can be possible though disarmament, creating the right conditions for women's empowerment and women's meaningful participation. This requires listening to local defenders of women's rights and human rights and benefiting from their experience. These actors can offer accurate and insightful information on the diverse needs and requirements of the people to better understand the causes and drivers of conflict. Creating other institutional spaces to think outside the frames of war can lead to transformative anti-militarist and post-colonial cultures and practices of peace. Gender, conflict and peace are in complicated and contextspecific relationships, and creating circumstances for positive peace requires more than ritualistic tokens or protection mechanisms. It is important to overcome the stereotypes that women are victims, to acknowledge that men can also be victims of sexual violence and that peace should be both for men and women, should be multi-gendered and focus on gender. There is an urgent need to reframe 'peace as the creation of conditions that would make the response of violence unintelligible and nonsensical'. In this, women as full and equal participants 'in conflict-related processes should also be able to question militarism and promote the positive peace'.22
Gender, conflict and peace are in complicated and context-specific relationships, and creating circumstances for positive peace requires more than ritualistic tokens or protection mechanisms.

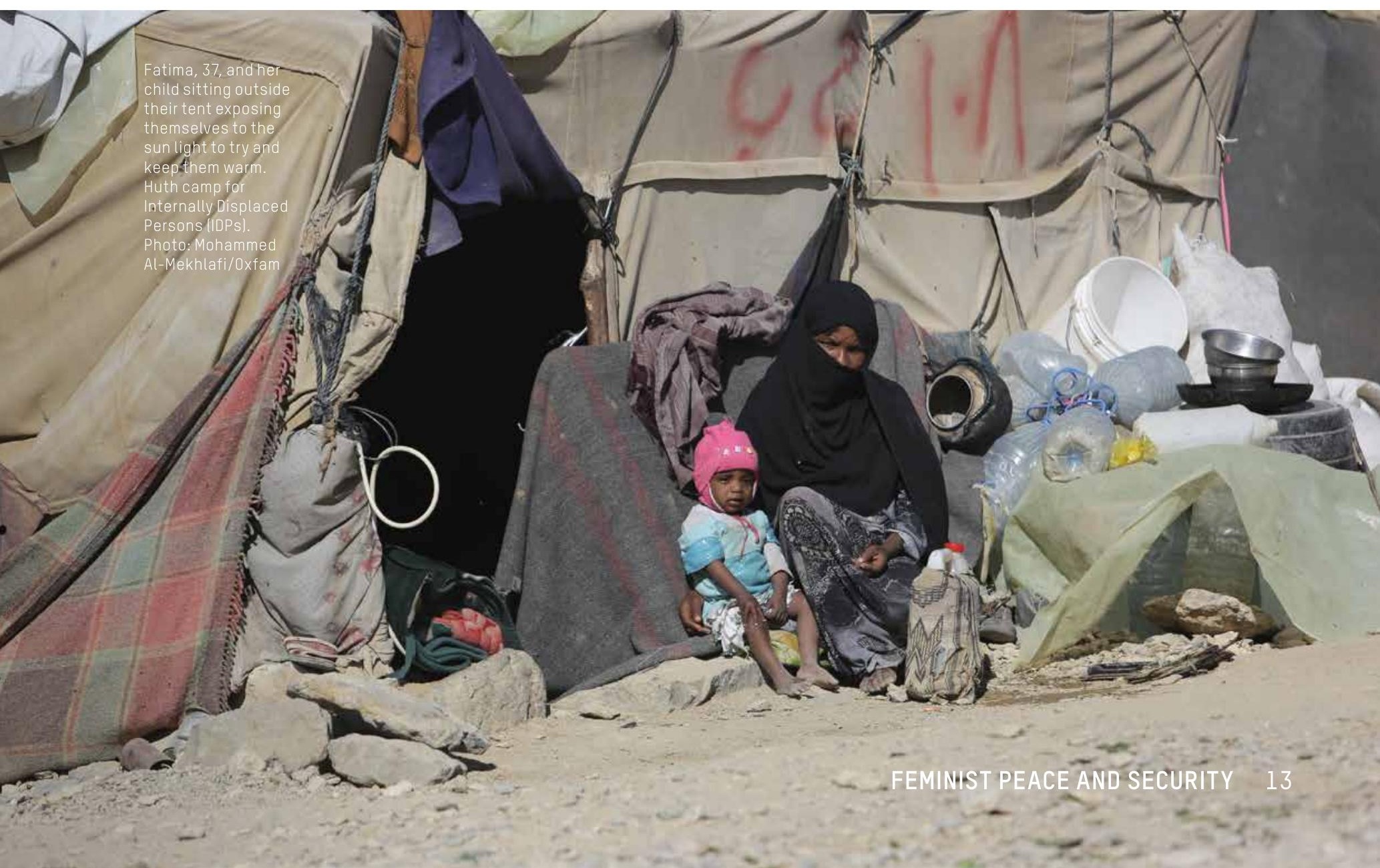


This section illustrates, through specific examples across the MENA, how and why gender-sensitive international frameworks are leading inadvertently to contradicting outcomes for achieving feminist peace and security. The issue areas in focus are preventing sexual violence in conflict; instrumentalization of WPS through CVE; the politics of donor funding; and the resilience policy framework.

\section{Protection vs prevention}

In order to achieve transformative feminist peace, a shift from protection alone to the prevention of conflict needs to take place. In some cases, international frameworks even utilize the protection principle to justify the use of force. ${ }^{23}$ Equally, protection is used to instrumentalize women's participation in security forces, such as employing women in peacekeeping to provide better protection for local women and children against sexual violence.

The prioritization of protection over prevention reinforces a general sense of the Security Council's 'fortitude and dependability' as a protector of vulnerable civilians. ${ }^{24}$ This promotes the symbolic importance of the Security Council's masculinized military methods as crucial to ensuring security. Its focus on sexual violence also diverts the attention of the Security Council members away from the failure to attend to the underlying structural causes of armed conflict; in particular the inequitable distribution of global power and wealth. Wider normative political, economic and social structures that play a larger role than assumed in leading to gender-based and sexual violence in conflict are overlooked. Sexual violence in conflict is part of a spectrum of genderbased violence caused by normalized and systemic discriminative and unequal structures shaping women's everyday lives and sanctioning male aggression. ${ }^{25}$

Justifications for the use of violence and experiences of violence are typically intersectional, meaning multiple identity-related or structural factors intersect to make certain groups more vulnerable. Militant radical groups such as ISIS use specific gender norms in connection with perceived religious or sectarian identities in order to morally justify and organize violence. ISIS reinforced gender norms that perpetuate patriarchy and men's control over women to organize the lives and behaviours of its recruits and the people under its control. ISIS's sexual violence against the Yazidis is part of a continuum of violence, and is related to structural gendered inequalities in society in general, specifically ISIS'S gender norms and the wider inequalities in Iraq. Moreover, their religious identity and minority position intersected with their gender to make Yazidi women and girls targets of sexual violence. Specific ethnic or religious constructions of identity intersect with gender, leading to the targeting of minorities, which may be based on ethnicity, religion or political affiliation. ${ }^{26}$ ISIS's ideological propaganda documents not only justify violence but also normalize and institutionalize it; and do so in the context of very specific identity-based claims that intersect with explicit commodification of women from minority communities.

Attempts to challenge this narrative have proved largely futile to date. Recent WPS resolutions that emphasise improving women's socio-economic conditions (including education and health services) and take a holistic view to peace,

\author{
Sexual violence \\ in conflict is part \\ of a spectrum of \\ gender-based \\ violence caused \\ by normalized \\ and systemic \\ discriminative and \\ unequal structures \\ shaping women's \\ everyday lives and \\ sanctioning male \\ aggression.
}


including politics, security, human rights, the rule of law and justice, are overlooked in favour of a focus on sexual violence in conflict. There can be little doubt that the primary aim is to make conflict safer for women rather than preventing conflict.

\section{The further instrumentalization and securitization of WPS through CVE}

The counter extremism framework in SCR 2242, which was particularly focused on responding to rising extremism in the MENA region, directly linked the WPS agenda to CVE. SCR 2242 seeks women's participation in countering extremism, and seeks to benefit from the work of women's rights organizations in developing and implementing strategies. Once again, although the engagement with women's organizations is welcome, this has a significant unintended consequence: it has led to the instrumentalization of the WPS agenda whose role is now to strengthen CVE efforts without increasing women's agency. There is, and should be, a fundamental disconnect between the CVE and WPS agendas. The WPS agenda is the outcome of a movement for demilitarization, while CVE is a security-focused policy implemented by armed or police forces. Dialogue and cooperation between the two agendas demand compromises and risks, undermining the foundations of WPS. Indeed, it should be questioned whether it is possible, or desirable, to bring WPS and CVE together in the name of making the latter more effective.

As already noted in the case of the UN Security Council, security-related decision making takes place in a highly masculinized culture and in maledominated and exclusionary spaces. But this is also evident beyond the UN and it is now clearly evident in CVE too. The 2016 EU Foreign Policy Strategy reveals a patriarchal and exclusionary foreign policy, adopting a 'hard' security approach by placing counter-terrorism and CVE at the heart of its strategy for protecting citizens from terrorist threats. ${ }^{27}$ The masculinized culture in these platforms continues despite efforts to enhance women's voices and diversification in the composition of stakeholders participating in policy making in recent years. The short-term national security objectives of CVE policies are often at odds with the long-term feminist peacebuilding goals of tackling the root, structural causes of armed violence. Integrating CVE work into WPS risks overlooking WPS as a standalone goal and reduces it to a means to achieve a securitized aim.

Another incompatibility between CVE and WPS is that CVE programmes reinforce gender stereotypes and contradict the idea of empowering women. Heteronormative thinking presumes that women and men have natural roles in life, and such thinking is implicitly evident in CVE. Women are portrayed as innately peaceful, as peacebuilders or community organizers. CVE programmes focus on women as victims of violent extremism and reduces them to their roles as mothers, sisters and wives of terrorists or future terrorists. Typically, gender stereotypes mean that both women's role as supporters or perpetrators of violent extremism, as well as men's role in preventing or countering violent extremism are absent from CVE programmes.

Furthermore, women who are involved in CVE activities are often praised for their personal involvement rather than their political agency, thereby confirming rather than challenging prevailing gender norms. Many such programmes assign a disproportionate responsibility to women in preventing or countering violent Women who are
involved in CVE
activities are
often praised for
their personal
involvement
rather than their
political agency. 
extremism. This may over-estimate their influencing power and put them at risk; or, conversely, may negate the work they do outside a CVE framework, only recognizing their CVE contribution.

The impact of linking CVE and WPS on feminist peace activism in the MENA region is highly worrying. The policy specifically targets MENA countries and huge amounts of funding are allocated by states and the UN for this policy, reducing funding for other non-security issues that are perceived as less important. This could undermine or contradict much of the groundwork done by women's organizations and force them to shape their agenda and goals to fit CVE to receive funding. The way CVE was incorporated in the Jordanian NAP (2018-2021) is a case in point. The plan was co-prepared by the Jordanian National Commission for Women and UN Women, and in collaboration with UNHCR. The Plan specifically addresses CVE by highlighting the role of civil society and women as key partners in preventing and countering violent extremism. It has been said that the Plan was informed by extensive local consultations. However, the decision to incorporate CVE into the plan was taken by the drafters unilaterally without consultation or conversations with women and women's organizations. It shows that seemingly grassroots activity is undermined by the top-down imposition of CVE work to enlist women's involvement in the implementation of this policy.

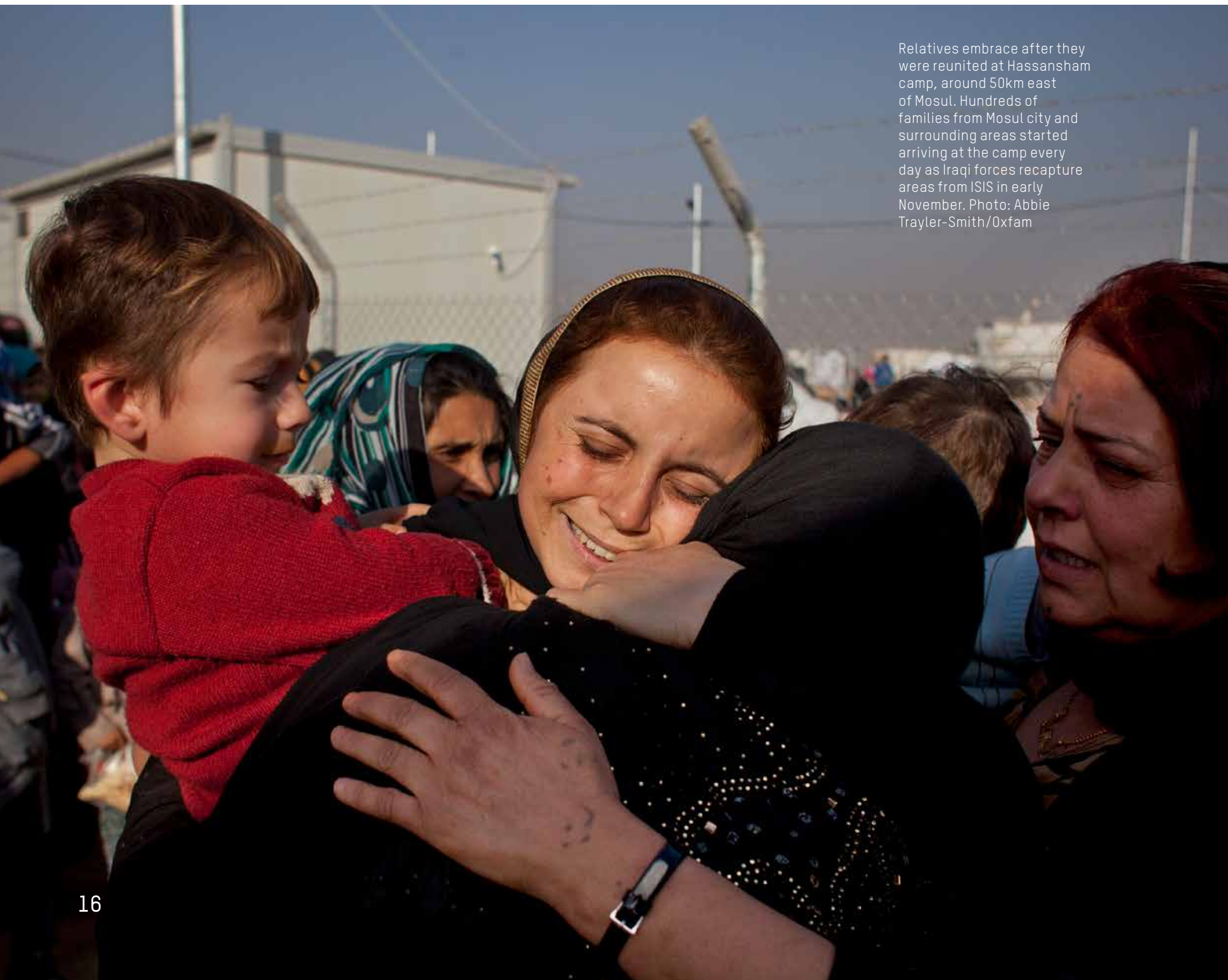




\section{Donor/funder politics - how local work is influenced}

The work of women's rights organizations and women activists has had to transform in order for organizations in countries affected by conflict to survive. They are constrained by a particular context in which funding is often only available for certain international policy agendas. Women's rights organizations in MENA reallocate their resources, goals and expertise to fit with an international agenda with a typically short-term, often humanitarian focus which can sometimes undermine years of women's rights gains in a national context. This also has long-term implications for these organizations and can undermine the work for women's and girls' rights that they were established to carry out. Organizations end up having to repackage their existing work under the WPS umbrella to be eligible for funding. If they do not use the language of the resolutions, they are overlooked and discredited. Moreover, financial rules imposed on civil society organizations lead CVE funding to be assigned to multilateral organizations or INGOs rather than directly to grassroot organizations. Financial rules and regulations designed to reduce the risks for funders negatively affect the resources and operating capacity of the organizations on the ground. The trickle-down effects from large organizations to smaller local organizations do not necessarily benefit the latter in carrying out their own agendas on enhancing women's rights and contributing to conflict resolution and peace processes. ${ }^{28}$ This restricts the space for grassroots feminist change.

For example, since the displacement crisis further escalated across the Middle East, donor funding has been channelled to humanitarian projects focusing on IDPs and refugees. This was important and necessary; however, it came at the expense of a sudden shift in the focus of local organizations' project work in Syria, Iraq, Jordan, Lebanon, Yemen, Turkey and other conflict-affected and refugee-receiving countries in the region. According to a study carried out at the American University of Iraq-Sulaimani in 2018, women's rights organizations had to stop their projects concerned with shelters for women, female genital mutilation and sexual and gender-based violence. Instead the donors come with ready-made projects with pre-set aims, budgets and of (very short) duration. Local organizations reported experiencing powerlessness and stated they were not consulted when it came to setting the agenda despite their intimate knowledge on the ground. They felt obliged to accept the terms of the funders as otherwise they would not survive. A representative of one of the organizations stated that they would prefer for funders to be willing to take advice and treat them as partners rather than subordinates, which she believed would lead to more sustainable and productive outcomes.

Donors' security concerns push civil society organizations from rights-based agendas to securitized agendas as seen in the CVE and stabilization work in the MENA region. CVE programming has significant financial implications for the rights of women and girls. ${ }^{29}$ Donors increasingly direct their funding to civil society organizations that are conducting CVE programmes. The CVE policy in the MENA region has demanded a change in the day-to-day work of civil society groups in conflict-affected contexts, pulling them away from work on women's and girls' rights. Civil society organizations are thus tempted to re-label their peacebuilding activities in terms of CVE. This leads to issues, capabilities and advocacy work being framed in terms of the objectives of funders, in line with those of policy makers. What is more, the tendency to focus on short-term security objectives rather than long-term peacebuilding efforts decreases the funding opportunities for organizations working in low-level long-term conflicts.
Local organizations reported experiencing powerlessness and stated they were not consulted when it came to setting the agenda despite their intimate knowledge on the ground. 
My research on Yazidis and sexual violence in conflict in Iraq also drove similar conclusions. During my fieldwork, the director of one of the women's rights organizations pointed to the prevalence of short-term securitized international responses that do not consider long-term impacts. She emphasised that the focus is on eliminating ISIS without addressing the root causes; therefore ISIS or some variant of it will come back. As a result, international actors and funders channel significant amounts of money for specific projects in a short period and then withdraw, creating obvious challenges for building sustainable grassroots activism. ${ }^{30}$

\section{Resilience policy: shifting responsibility to women}

Resilience interventions consider vulnerabilities mainly as embedded in societal practices, and aim to reduce vulnerabilities through empowering individuals and communities. ${ }^{31}$ Their emphasis on human capacities, the ability of individuals and communities to cope with challenges and even come out of it stronger, sound intuitively appropriate. This kind of bottom-up approach, combined with the idea of responding to a long-term need for resilience, also fits with the aim of generating sustainable and peaceful societies. As such, few would fault its underlying aspirations. ${ }^{32}$

The assumptions implicit in the resilience policy framing, however, mean that this approach is not well-suited to respond to all types of humanitarian or development issues.

First, resilience policies make communities the site of solution for problems that are not necessarily created at community level. This is clearly seen in Iraq and Syria today. Existing resilience policies in response to displacement in these contexts, despite their effort to include women and a gender perspective in their programmes, remain limited in their potential to address gendered impacts of displacement. For instance, the Regional Refugee and Resilience Plan (3RP) 2016-2017 for Iraq and Syria states that 'The Resilience component of the 3RP, led by UNDP, is aimed at addressing the longer-term self-reliance of individuals and communities'. The plan emphasises cultural norms in resilience strategies but overlooks the specific rules, regulations, laws and practices within the societal, economic and political context that underlie, generate and exacerbate vulnerabilities in these countries. Yet, such an approach is necessary to understand the underlying economic, political and societal factors that render women and men vulnerable to the impact of displacement. This is necessary to identify appropriate responses to addressing the gendered impacts of displacement.

A resilience approach is essentially apolitical, which is the opposite of feminism. It rarely explores or addresses the political crisis which could be driving fragility and completely fails to use a political economy lens. Putting the responsibility on women and communities to be resilient to what is happening to their lives and adapt to the situation perpetuates the colonialist interventionist mentality and overlooks underlying causes. It shifts the responsibility from those who caused the conflict and instability (both national and international actors), to communities, and this is unfair. The idea that through developing the resilience of individuals and communities, such as by economically empowering women, these cultural impediments can be overcome is unrealistic, because such a view overlooks the more crucial 
barriers that create gendered vulnerabilities for women in the first place.

These barriers and challenges derive from institutional, procedural and legal practices implemented by national and international authorities in Iraq and Syria, in refugee-receiving countries. The authoritarian nature of these regimes also do not allow for civil activism, public debate and societal pressure on the governments to initiate institutional change. These regimes have benefited from the perpetuation of the existing structures and inequalities.

Resilience policy also overlooks the historical responsibilities of the international actors that render certain parts of the world poorer or insecure. The vulnerability of women in conflict-affected contexts in MENA is significantly caused by long-term economic deprivation, political instability, lack of government investment in infrastructure, conflict and war.

\section{CONCLUSION}

A feminist approach to peace and security has the potential to deliver genuine conflict transformation in MENA, placing the emphasis on securing positive peace and eliminating long-term structural drivers of conflict and drawing attention to the need to eliminate intersecting factors that render particular groups especially vulnerable and disempowered.

However, existing discourses and frameworks that seek to draw on feminist approaches primarily do so through the WPS agenda. The current framing of WPS embodies a number of limitations which greatly inhibit its transformative potential, place the focus on short-term securitization at the expense of long-term inequalities, reduce the agency of women, and reinforce masculine frameworks in many instances. What is more, this approach to WPS is often imposed on local communities in the MENA region through external donor-local actor relations that sit within a wider long-term context of global inequalities and western self-interest.

For the current failures to be tackled and the potential of feminist approaches to be fully realized, a number of measures need to be addressed, all of which are highlighted by applying a feminist lens to conflict in the region. The intersection of identities must be acknowledged, and the reinforcing effect of multiple factors needs to be acknowledged and tackled. The WPS agenda must be seen as a rights-based and long-term process that seeks to fight underlying structural drivers of conflict rather than reducing it to a securitizing framework. Women and girls should have their agency restored, and genuine empowerment should be pursued. International donors and actors should have long-sighted and sustainable solutions. Donors, INGOs and states should focus on supporting locally driven and inclusive solutions. A bigger role falls to INGOs in challenging the donor framework, in building new processes and creating new spaces. The current WPS framework limits the ability to influence and carry out advocacy in this regard. Therefore, Oxfam could put more effort into challenging the current donor framework.

Indeed, there is a minority of isolated but notable examples that are challenging the dominant limiting approach to WPS in the region and seeking to shift the focus from militarized security to a more comprehensive conception of security that involves socio-economic rights, everyday liberties, access to 
basic services and enjoyment of rights. In Palestine, women's meaningful participation is increasing due to the work of civil society organizations that help build capacity and raise awareness of women's rights. In Libya, womenled organizations share experiences of other women in conflict. In Yemen, women have been calling for establishing a Joint Investigation Commission to ensure accountability and facilitate bringing justice to victims. International organizations and donors should seek to support this work rather than undermining it with the imposition of their own agendas, which ultimately have the consequence of inhibiting a feminist peace, even though they may well be striving to achieve this.

The transnational and complex nature of international relations today provides more opportunities for creative strategies that link different feminisms and that facilitate the co-existence of different conceptions of empowerment and different forms of cooperation. Seeing the world in this way offers more possibilities for those who seek transformative change towards meaningful inclusion and positive peace. The entry points for initiating and supporting change have multiplied in this more complex and transnational world. Long-term historical inequalities that are result of previous structures of dominance continue to shape contemporary relations; they have not disappeared. But they manifest themselves in multifaceted and less obvious ways, although they are also less robust. This means that feminist peace activists can think in creative ways to infiltrate through the cracks and transform the existing structures. Encouragingly, gender is now an official component of international normative and political frameworks, and increasingly more states are adopting the WPS agenda. The WPS agenda has several limitations, as discussed in this paper. But rather than rejecting the agenda completely, the agenda could be re-defined and its assumptions could be challenged by drawing attention to its negative impacts on the ground and by highlighting local demands for feminist peace.

This work should put more effort into building more grounded processes through amplifying and enhancing voices from the ground. The process should be inclusive and reflect the diversity of experiences. Women's International League for Peace and Freedom's work in this regard is notable. ${ }^{33}$ Another example is the challenge posed by the joint work of the LSE Centre for Women Peace and Security and GAPS to the UK government's inclusion of CVE in its WPS programming. Even though CVE remains a part of UK's WPS agenda, UK government officials at least verbally highlighted their increased awareness of the contradictions of this programme and committed to attempt a more nuanced and careful approach in their work in the MENA region. The hope for transforming the WPS agenda to its feminist roots should be maintained, and more feminist agendas should be adopted by women's rights activists and organizations. 
1 Statistics about exposure to sexual violence in conflict in the Middle East are not reliable but they give an indication of the scale of the issue. For instance, in Yemen exposure to sexual violence increased from 9\% before the conflict to $30 \%$ at the time of writing. Six months after the eruption of the conflict, incidents of SGBV increased by $60 \%$, see UN Secretary-General. 2018. Report of the Secretary General on ConflictRelated Sexual Violence. S/2018/250. In Iraq, 6.800 Yazidis were kidnapped, most of them women and children, with women experiencing sexual violence. FIDH and Kinyat Organization for Documentation. 2018. Sexual and Gender-Based Crimes against the Yazidi Community: The Role of ISIL Foreign Fighters. No. 723a.

2 Cynthia Enloe. (2014). Bananas, Beaches and Bases: Making Feminist Sense of International Politics. University of California Press.

3 UNDP. (2015). Resilience Building in Response to the Syria Crisis. Amman

4 C. Enloe. (2014). Bananas, Beaches and Bases. Op. cit.

5 D. Otto. (2016). Women, Peace and Security: A Critical Analysis of the Security Council's Vision. LSE WPS Working Paper Series 1. P10

$6 \quad$ Ibid. Pp2-3

7 N. Pratt and S. Richter-Devroe. (2013). Women, peace and security: new conceptual challenges and opportunities. Policy Brief. Norwegian Peacebuilding Resource Centre. P3

8 S.E. Davies and J. True. (2015). Reframing conflict-related sexual and gender-based violence: Bringing gender analysis back in. Security Dialogue 46(6): 495-512.

W. Giles and J. Hyndman. (2004). Sites of Violence: Gender and Conflict Zones. University of California Press.

9 N. Pratt and S. Richter-Devroe. (2013). Women, peace and security. Op. cit. P3

10 Ibid.

11 C. Bell and C. O'Rourke. (2010). Peace Agreements or Pieces of Paper? The Impact of UNSC Resolution 1325 on Peace Processes and Their Agreements. International and Comparative Law Quarterly 59.

12 H. Safran. (1995). From denial to equal representation: Women's peace groups and the creation of new feminist activism in Israel. Women in the Conflict. 2(3).

13 S. Gibbings. (2011). No Angry Women at the United Nations: Political Dreams and the Cultural Politics of United Nations Security Council Resolution 1325. International Feminist Journal of Politics 13: 522-38.

14 S. Sharoni. (2017). Gender and resistance to political violence in Palestine and Israel. In: Simona Sharoni, Julia Welland, Linda Steiner and Jennifer Pederson (Eds.) Handbook on Gender and War. Cheltenham: Edward Elgar, 380-399.

15 UNODA. Arms Trade. https://www.un.org/disarmament/ convarms/att/
16 D. Otto. (2016). Women, Peace and Security. Op. cit. P10

17 Ibid. Pll

18 N. Al-Ali and N. Pratt. (2009). What Kind of Liberation? Women and the Occupation of Iraq. University of California Press.

19 Ceasefire Centre for Civilian Rights. (2018). Civilian Activists under Threat in Iraq. Report. Minority Rights Group International. London.

20 A. Tickner. (2019). 'Peace and security from a feminist perspective.' In: S.E. Davies and J. True (eds.) The Oxford Handbook of Women, Peace and Security. New York: Oxford University Press, pp. 15-25.

21 N. Pratt and S. Richter-Devroe. (2013). Women, peace and security. Op. cit. P3

22 D. Otto. (2016). Women, Peace and Security: A Critical Analysis of the Security Council's Vision. LSE WPS Working Paper Series 1.

23 G. Heathcote. (2011). Feminist politics and the use of force: theorising feminist action and Security Council Resolution 1325. Socio-Legal Review 7: 23-43.

24 D. Otto. (2016). Women, Peace and Security. Op. cit. P9

25 W. Giles and J. Hyndman. (2004.) Sites of Violence: Gender and Conflict Zones. University of California Press. P3-5; L. Kelly. (2010). The everyday/everynightness of rape: Is it different in war? In L. Sjoberg and S. Via leds.) Gender, War and Militarism: Feminist Perspectives. Santa Barbara, CA: Praeger.

26 S.E. Davies and J. True. (2015). Reframing conflict-related sexual and gender-based violence. Op, cit. P505

27 LSE WPS. (2017). Preventing/Countering Violent Extremism and Women, Peace and Security: Concepts, Practices and Moving Forward. Centre for Women, Peace and Security, London School of Economics.

28 Duke International Human Rights Clinic and Women Peacemakers Program. (2017). Tightening the Purse Strings: What Countering Terrorism Financing Costs Gender Equality and Security. Report. Duke University School of Law.

29 Ibid.

30 Z.N. Kaya. (2019). Yazidis and ISIS: Causes and consequences of sexual violence in conflict. LSE Middle East Centre Paper Series.

31 D. Chandler. (2013). International Statebuilding and the Ideology of Resilience. Politics 33 (4) (2013): 276-286.

32 Z.N. Kaya. (2018). Resilience Policy and Internally Displaced Women in Iraq: An Unintentionally Flawed Approach. LSE WPS Working Papers Series 13, London.

33 Women's International League for Peace and Freedom. (2019). Statement: Ensuring inclusion of Syrian women in the mediation of the conflict. 
